\title{
Public-Private Partnership-Institute of Socially Oriented Economy and Democratic Management System
}

\author{
Viktoriya I. Tinyakova, ${ }^{1, *}$, Natalia I. Morozova ${ }^{2}$, Valentina N. Tarasova ${ }^{3}$, Oksana V. \\ Konovalova $^{4}$
}

\author{
${ }^{1}$ Project Management Department, State University of Management, Moscow, Russia \\ ${ }^{2}$ Volgograd Cooperative Institute (branch) of the Russian University of Cooperation, Volgograd, Russia \\ ${ }^{3}$ Department of Transport Innovation Management at the Institute of Transport Engineering and Control Systems, \\ Russian University of Transport, Moscow, Russia \\ ${ }^{4}$ Financial University under the Government of the Russian Federation, Moscow, Russia \\ Corresponding author. Email: vi_tinyakova@guu.ru
}

\begin{abstract}
Today, the leading world powers define the construction of a social state as a priority direction for their development. Authorities are expanding their social and economic obligations that will be financed at the expense of means of budgets of various levels. However, the revenue part of the budget is not growing at such a rapid pace, which leads to a budget deficit and calls into question the implementation of the increased social obligations assumed. This situation has not only economic but also political consequences. It may lead to increased social tension and expressions of distrust of the current government. In this regard, it is necessary to find new tools and mechanisms for financing social obligations of the state, to attract financial resources of private investors in the provision of social services. Introduce market mechanisms in the management of public services, thereby reformatting the very concept of state and municipal management. For a long time, it was considered that financial management tools are not applicable in the public and municipal sectors. However, the "efficiency" and "effectiveness" criteria widely used in the private sector can be used to evaluate the performance of public authorities and control budget spending. A promising mechanism for transforming the role of the state in the economy and strengthening private initiative can be public-private partnership (hereinafter - PPP), which can be considered as a voluntary Union of the public and private sectors in the implementation of social investment projects that stimulate the solution of national tasks. Unfortunately, even today there is no unified approach to determining the essence of this phenomenon and its characteristic features. All this makes it difficult to implement this mechanism in practice. Creating a legal Foundation and institutionalizing the main forms of such cooperation will contribute to the formation of social partnership and the development of civil society in Russia. In addition, expanding the scope and intensity of PPPs in the economy will increase the investment attractiveness of the territory and the development of the private sector, which will have a positive impact on the quality of life of the population. Keywords: public-private partnership; socially oriented economy; quality of life of the population; social infrastructure; democratic management system; social investments

\section{INTRODUCTION}

Today, the focus on expanding social services provided to every citizen is becoming a strategic vector for the development of the world's leading powers. Creating conditions for comprehensive human development and improving the quality of life of the population - these are

the key tasks of modern society. The state can no longer play a passive role in the economy or adhere to the principle of "Laissez-faire", but it is also impractical to take a paternalistic position in a free market economy. It is necessary to build a model of relations between the state and the private sector that would increase the social responsibility of business and make the public sector more attractive for investment. This point of view is also shared by experts of the International monetary Fund,
\end{abstract}


emphasizing that the state in the context of globalization should play a more significant role, and entrepreneurs can be involved in the development of areas that have traditionally been considered public (education, health, utilities, etc.). This will increase the efficiency of their operation [1].

Partnership between government agencies and entrepreneurs is the Foundation, the cornerstone, that is necessary for building a socially oriented management system with integrated elements of democratic control of society over public authorities. Cooperation, not confrontation and total control-these are the guidelines that a modern state should strive for [2-4].

The financial benefits of the partnership include the following. Attracting private investment will reduce the budget deficit that arises in the context of increasing social obligations and the need to modernize the worn-out social and industrial infrastructure. However, social investment projects require serious capital investment, which may not pay off or their repayment period will be very long. This contradicts the business goals and acts as a deterrent to their participation in such projects. However, the lack of infrastructure or its severe deterioration can become an obstacle to the successful expansion of business activities. At the same time, private business is not able to implement large-scale projects independently, without the help of the state. Thus, the state and business are forced to find common ground and conduct a constructive dialogue in the search for new mechanisms to attract investment from private entrepreneurs to solve national problems and improve the financing of the social sphere.

In addition, there is an increasing need to reformat the process of organizing the work of industries that provide public services, and to improve the efficiency of state property management. This type of problem can be solved by introducing financial management procedures and standards into the public administration mechanism, which will allow modernizing the existing management system in the public sector.

\section{METHODOLOGY}

During the research, the authors used General scientific methods and approaches: comparative, systematic, and retrospective-historical. These methods are aimed at obtaining an objective picture of the existing reality from different epistemological points of view. Despite the differences in their worldview, we considered and used General scientific methods and approaches as complementary, not mutually exclusive forms of scientific knowledge. This is due to the desire for multidirection in explaining the reasons for the development of publicprivate partnership as an institution for building a socially oriented economy and the rule of law. We emphasize once again that to use different methods and approaches to explain the essence and reasons for the evolution of interaction between government and business on the principle of "either - or" means to exclude a multidimensional vision of the phenomenon under study.

\section{DISCUSSION}

In the scientific literature, various terms are proposed to describe the new form of relationship: private-public partnership, public-private partnership, private-public entrepreneurship, public-private partnership (hereinafter PPP), and a number of others. All the presented interpretations reflect the same phenomenon - the interaction of the state and private business on mutually beneficial terms in the field of entrepreneurship to solve socially significant and national problems. However, such cooperation should be initiated by public authorities. They are the initiators of a large number of investment projects in the field of PPP, their coordinators and main actors. This is due to the fact that the object of investment is state and municipal property. This is the basis for establishing partnerships between the state and the private sector. On the other hand, only the state can create favorable conditions for business and make the social sphere attractive for investment by providing entrepreneurs with state guarantees, benefits, and large amounts of state property. Therefore, the emphasis in the definition should be on the word "state". This approach has led to the fact that the term "public-private partnership" has become more widely used in the scientific literature, and we will use it in this study.

Despite the fact that the PPP mechanism has great potential in its development, especially in the context of increasing budget deficits and expanding social powers of the state, scientists and practitioners have not yet come to the development of a universal, universally recognized definition of the term "public-private partnership". Many researchers, both in Russia and abroad, hold different points of view when determining the essential features and main differences of this mechanism from other forms of attracting investment and cooperation [5-13]. The absence of a theoretically developed model and legal regulations creates conditions for the transfer of state assets to the private sector using corruption schemes, which contradicts the state interests, threatens national security and does not meet the requirements for improving the efficiency of state property management. In order to develop a national model of interaction between the state and the private sector, it is necessary to conduct a critical analysis of the experience accumulated in Russia and foreign countries in this area, which will determine the strategic vector of its further development.

Here are the most common definitions of PPP proposed by reputable international organizations and researchers. According to the world Bank experts, the PPP mechanism can be considered as a legal act concluded between public authorities and business in order to attract the missing investment resources for the implementation of the 
production process or the provision of infrastructure services. This agreement reduces the burden on the budget and increases the efficiency of using budget funds allocated to the social sphere. This definition describes the General contours of the phenomenon under consideration, does not reveal the features of this mechanism and its differences from other tools, and can not give an answer to the question of how risks and responsibilities will be distributed among the participants of the partnership, which makes it difficult to implement this mechanism in practice.

The countries of the European Union have also adopted a large number of regulations and conducted research in the field of PPP [14, 15]. However, a universal approach has not yet been developed, and a common formulation has not been proposed that reveals the essential features of this phenomenon and its distinctive features. The Green paper "Public-private partnership and community legislation on public contracts and concessions" explicitly States that the term PPP at the Community level has not yet been defined. There is only a General approach, according to which PPP is considered as a special type of cooperation between authorities and entrepreneurs, the purpose of which is to attract investment, build, modernize and operate infrastructure or provide social services (Green paper on public-private partnership).

A more extended interpretation of this phenomenon is given by the international organization "Economic and social Commission of the United Nations for Asia and the Pacific", which describes the final results of partnership interaction, the rights and obligations of PPP participants, as well as the need to institutionalize relationships through legal acts. This document notes that the goal of cooperation between the state and business is to expand the number and improve the quality of infrastructure or social services provided to society. Relationships are based on a contract or other legal document that specifies the rights and obligations of the parties and their liability in case of non-compliance with the terms of the contract. Legal regulation of relationships helps to neutralize disputes and conflicts that may arise during the implementation of the project. This form of partnership implies that each of the parties is competent in its field, as well as the efforts of each participant will be aimed at solving national problems. In addition, the business partner of the state must meet certain criteria, the most important of which is that the company has been operating on the market for a long time and is financially stable.

A fairly General definition is provided By the international rating Agency Standard \& Poor's. Although here, in contrast to the definition proposed by the world Bank, it defines the period of cooperation (medium-term or long-term), the key points of interaction, as well as the expected benefits (pooling resources and competencies) and the scope of responsibility for the participant in this type of cooperation (sharing risks and income).

A number of foreign researchers emphasize that PPP has certain differences from the mechanism of privatization.
The main goal in the implementation of PPP projects is to increase the efficiency of using budget resources and the ability to fulfill their social obligations in full in the face of increasing budget constraints. Full and continuous provision of public services to the population increases the political significance of government bodies. This highlights the difference between PPP and privatization, in the course of which the state loses control over its assets, transferring (or rather selling) them to the private sector. In the case of a PPP, the state transfers only its economic functions (partially or completely), but reserves the control and regulatory levers. This helps you get away from administrative methods of influence and build partnerships with businesses. At the same time, we must not lose our presence in strategically and socially important sectors of the economy. This approach is in the interests of ensuring the country's national security.

The public organization Association of Managers in its report "business Risks in public-private partnership" focuses on the ultimate goal of partnership, on the benefits that society will receive, namely, the development of various sectors of the economy - from knowledgeintensive and capital-intensive to socially significant and low-profit. The successful development of the PPP mechanism requires its legal and institutional consolidation.

Most domestic PPP formulations are based on the definition given in official documents of the Organization for economic cooperation and development. According to this approach, the PPP mechanism is based on legally established norms. The project implementation period can be defined or indefinite. The agreement is concluded between the partnership participants-the state and a commercial organization. According to the agreement, both parties participate in the management decisionmaking process and provide resources in various forms, not only monetary, for the implementation of the goal set in the agreement. In this approach, the emphasis is on the fact that in PPP projects, the authorities are not regulators or overseers of the economic activities of economic entities, but rather catalysts and business partners. Despite the fact that the state has power, it does not exercise it in the process of participating in PPP projects. Public authorities have the same rights as private investors. This definition, in our opinion, is the most optimal and practically directed.

\section{RESULTS}

The PPP is aimed primarily at consolidation of resources of the state and business with the aim of mutually beneficial partnerships on a long term basis for the development of social or production infrastructure, landscaping or public services in health, education or social protection.

However, a PPP is not a simple addition of resources to an investment project aimed at improving the social sphere. 
In this agreement, the participants in the interaction try to realize their own goals and objectives, as well as have different motivational settings.

Thus, the authorities are trying to expand the number and improve the quality of services provided to the population and economic agents, thereby confirming their political viability.

Entrepreneurs want to maximize the size of their profits and get the opportunity for extended reproduction. In addition, receiving significant dividends "under the umbrella" of the state is a tempting prospect for any private investor.

More successful and attractive in the eyes of private investors will be the project in which the conflicting interests of the public and private sector will find their solution. In other words, the implementation of the project will improve, for example, the infrastructure, which will meet national goals and stimulate the growth of the quality of life of the population. But at the same time, business investment resources attracted to the development of the social and industrial sphere will give an additional impetus to reduce production costs in the private sector and increase its competitive advantages. If the partnership participants acted independently, the implementation period of such projects would be longer and less effective. By establishing a mutually beneficial partnership, it is possible to resolve the growing contradiction and find a compromise solution (figure 1).

\begin{tabular}{|c|}
\hline Polity \\
\hline $\begin{array}{c}\text { Development of social and industrial } \\
\text { infrastructure }\end{array}$ \\
\hline $\begin{array}{c}\text { Increasing the number and improving } \\
\text { the quality of services provided to the } \\
\text { population and economic agents }\end{array}$ \\
\hline $\begin{array}{c}\text { Organization of work of public } \\
\text { service industries on market } \\
\text { principles }\end{array}$ \\
\hline $\begin{array}{c}\text { Improving the effectiveness of state } \\
\text { property management }\end{array}$ \\
\hline
\end{tabular}

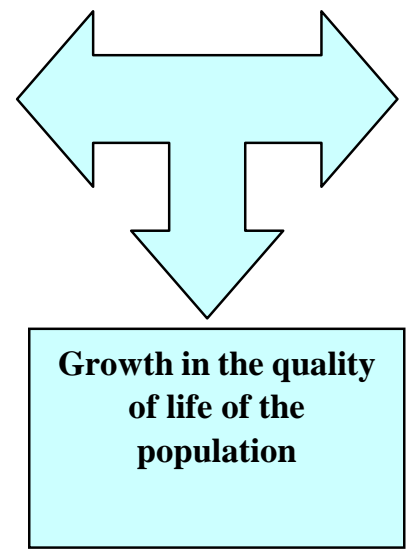

\begin{tabular}{|c|}
\hline Business \\
\hline $\begin{array}{c}\text { Expansion of the space for free } \\
\text { movement of capital, penetration } \\
\text { into areas that were previously } \\
\text { inaccessible }\end{array}$ \\
\hline $\begin{array}{c}\text { Raising budget funds for the } \\
\text { implementation of the project }\end{array}$ \\
\hline $\begin{array}{c}\text { Expanding opportunities for } \\
\text { obtaining loans through } \\
\text { government guarantees }\end{array}$ \\
\hline $\begin{array}{c}\text { The possibility of obtaining tax } \\
\text { benefits and other preferences }\end{array}$ \\
\hline
\end{tabular}

Figure 1 Model of interaction between the public and private sector in the process of PPP implementation

Thus, combining efforts within the framework of the PPP project leads to a synergistic effect from the joint use of resources of the state and private entrepreneurs in the implementation of socially significant investment projects. It is the PPP that contributes to the transformation of the work of public services industries, introducing market principles into their management mechanism. This approach makes it possible to get the best value for money and significantly increase the level of satisfaction of the population with the social services received. Ultimately, society wins as a global consumer of better infrastructure and social services $[16,17]$.

The PPP mechanism allows the state to move away from administrative methods of influence in the field of entrepreneurship, replacing them with softer economic levers. By transferring full or partial economic functions to private businesses, the state retains control over the activities of its partners in the implementation of socially significant investment projects.

It is well known that there is a direct link between investment and economic development: an increase in investment in the development of the real sector of the economy leads to economic recovery and Vice versa. The multiplier effect should be used to ensure even economic development. To do this, it is necessary to choose such objects for investment that will create a longer-term economic effect and involve a larger number of enterprises working in this or related field of activity in the process of recovery. You can give a figurative comparison: if you throw a stone into the water, it will go circles. So the state needs to choose such objects, investments in which will help to revive a larger number of economic entities, create additional jobs, and increase the level of welfare of citizens.

The transition from direct to indirect, from administrative to economic methods of regulating the economy, contributes to the modification of the role of the state in the modern economy. This process is stimulated by the expansion of social obligations and increasing processes of democratization of the management system. The world Bank report emphasizes that the modern state is forced to abandon command and control methods of regulating business activity, preferring softer instruments of influence that contribute to the formation of civil society and involve more interested, economically active 
economic entities in the management process. Cooperation without the use of coercion, on a voluntary basis-becomes the main leitmotif of the modern state. As a result, the state transfers part of its regulatory powers to civil society institutions, whose main task will be to exercise democratic control over the activities of public authorities. All this will contribute to the accumulation of a critical number of new phenomena in the field of public administration. The development of this process will lead to the fact that in the near future a new mechanism of self- regulation may arise, which is fundamentally different from the classic market mechanism.

The PPP mechanism allows you to flexibly regulate the degree of control over the processes of providing public services to private partners by the state. Thus, the interest of a business increases if it is delegated more authority and expands its sphere of responsibility, and Vice versa. The evolution of the level of business involvement and the corresponding forms of PPP is shown in figure 2.

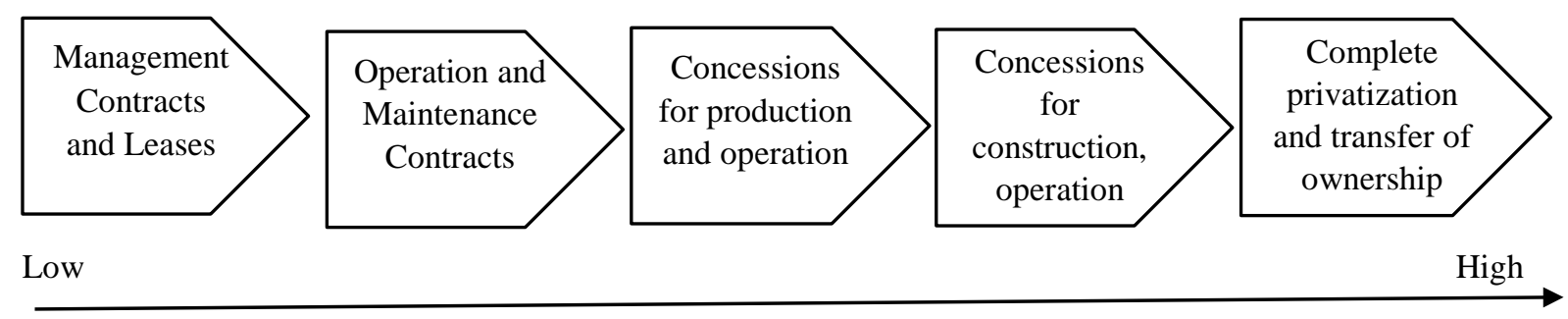

Level of involvement and degree of freedom of the private sector

Figure 2 Classification of PPP forms in terms of the level of involvement of entrepreneurs and their degree of freedom in the implementation of PPP projects

As you can see from the figure, the extreme form of PPP development is the privatization of state or municipal property, which leads to the complete loss of state control over assets.

The privatization programs widely used in Russia during the period of transformational changes were aimed at increasing the number of private enterprises in the economy. However, this process did not have the expected effect, but, on the contrary, led to the degradation of the social nature of production and the loss of control functions of the state in strategically important sectors of the economy. This is partly because the reformers ' focus was not on improving production efficiency, but rather on abandoning the public sector for ideological reasons. Thus, the excessive interest in privatization as such, without taking into account its role in the organization of economic activities, as well as ignoring its main purpose to increase the competitiveness of individual economic units and the economy as a whole-has led to a perversion of the very idea of building a market economy.

In our view, it was necessary to provide for such forms and mechanisms of interaction between the state and the private sector that would allow an economic entity not just to integrate into the market system, but to become part of a single cycle of public capital. The goal cannot be the process of privatization or nationalization. The most important goal that public authorities should pursue is to increase the efficiency of the economy and the well-being of people. And in order to achieve it, various tools can be used, including privatization. The use of a particular method will depend on the specific situation. This idea is reflected in Convention No. 117, adopted by the
International labour organization in 1962. This document emphasizes that the state, when developing and implementing its political programs, must first of all take care of the growth of the population's welfare and social progress.

We believe that the mechanism of public-private partnership can become a full-fledged substitute for privatization. Under this mechanism, the state transfers all or part of its economic functions to the private sector, but retains the right to control the implementation of the project. This allows the private sector to fully implement the entrepreneurial initiative, and the state to keep the strategically important sectors of the economy under its control. In the XXI century, the time of the partner state comes to replace the sovereign state.

If to the factor - the level of involvement of entrepreneurs and their degree of freedom in the course of PPP project implementation, add the second factor-risk assessment and ways of its distribution among the participants of the PPP project, then you can get a different classification of PPP forms (figure 3 ). 


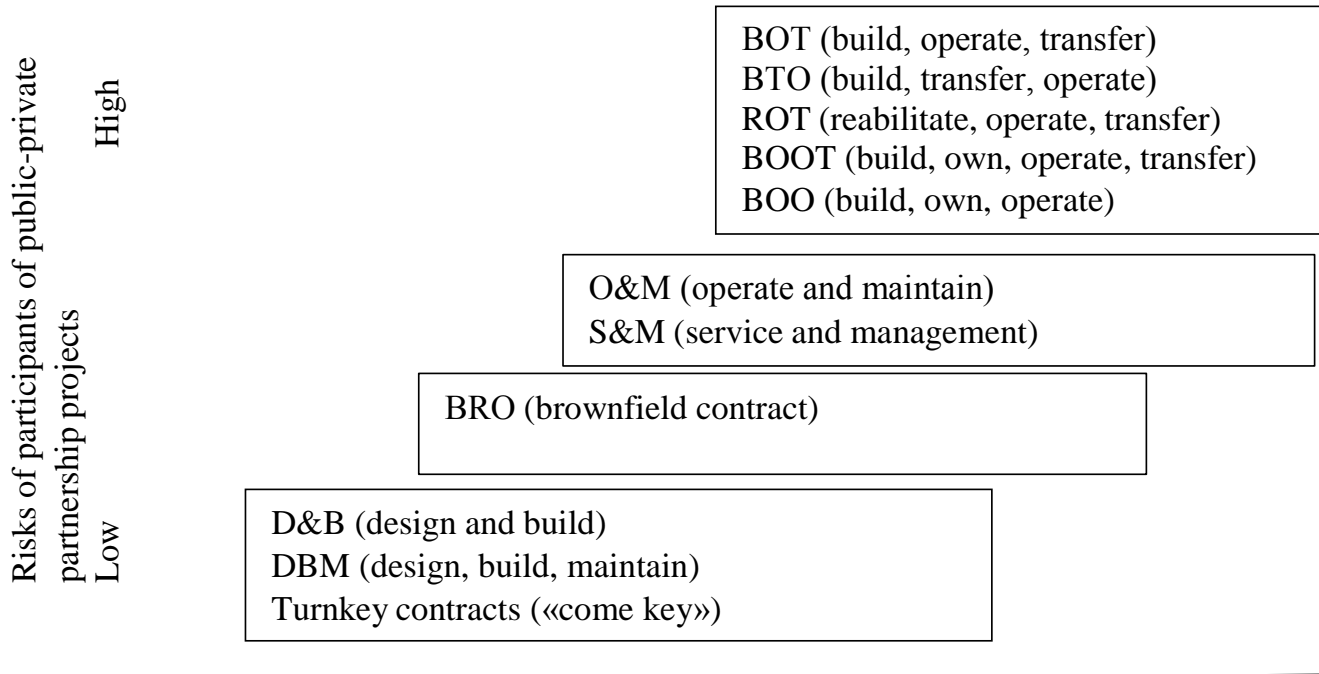

Low

Level of involvement and degree of freedom of the private sector

Figure 3 Two-Factor model of classification of PPP forms

Consideration of the PPP form helps us to identify the most characteristic features of PPP projects and their differences from other forms of cooperation between the state and business:

* regulated and extended terms of implementation of the agreement (from 10 to 50 years in the case of a concession);

* the target nature of the investment object (usually the project is created for a specific object);

- special form of project financing (joint use of private and budgetary funds);

* flexible form of responsibility and risk sharing among project participants;

- different levels of involvement of the private sector in partnership with the state;

* competitive selection of applicants for contracts.

\section{CONCLUSION}

Summing up, we note that the PPP mechanism is a progressive form of cooperation between government and business. Meanwhile, there is already a potential contradiction in their relations: the state is obliged to fulfill certain obligations, for the implementation of which the corresponding expenses are allocated, and the main goal of business is to maximize the amount of profit received. A peculiar point of convergence of interests is that the poor quality of the existing social or industrial infrastructure will hinder the development of promising business areas and reduce the level of execution of budget powers by the state.

Today in Russia, public-private partnership is getting more and more developed. This form of cooperation is becoming the main tool for stimulating territorial development in the Federal subjects and especially in municipalities. It is not surprising, because according to the Federal law from 06.10.2003 № 131-FZ (as amended on 27.12.2019) "On the General principles of the organization of local self-government in the Russian Federation", which defined the powers of local selfgovernment bodies, their share accounts for the main burden of maintaining social facilities in proper condition. However, the amount of revenue from the local budget is unlikely to cover current costs. The lack of financial resources at the local level encourages authorities to search for new tools to attract them. PPP can become a panacea that will improve the living conditions of citizens and stimulate business development without additional costs on the part of local governments.

As of the beginning of 2019, 3,422 PPP projects are being implemented in Russia with a total volume of attracted private investment of 2,182 billion rubles. For comparison, in China at the end of 2018, there were 4,691 PPP projects under implementation, with an investment volume of $\$ 1$ trillion, and in Kazakhstan-473 projects worth 90 billion rubles.

Thus, in Russia, the PPP mechanism is becoming more popular, but the amount of attracted investment from the private sector is still significantly behind foreign countries.

Figure 4 shows data on the dynamics of PPP development in Russia and the amount of private investment attracted for their implementation, by year. 


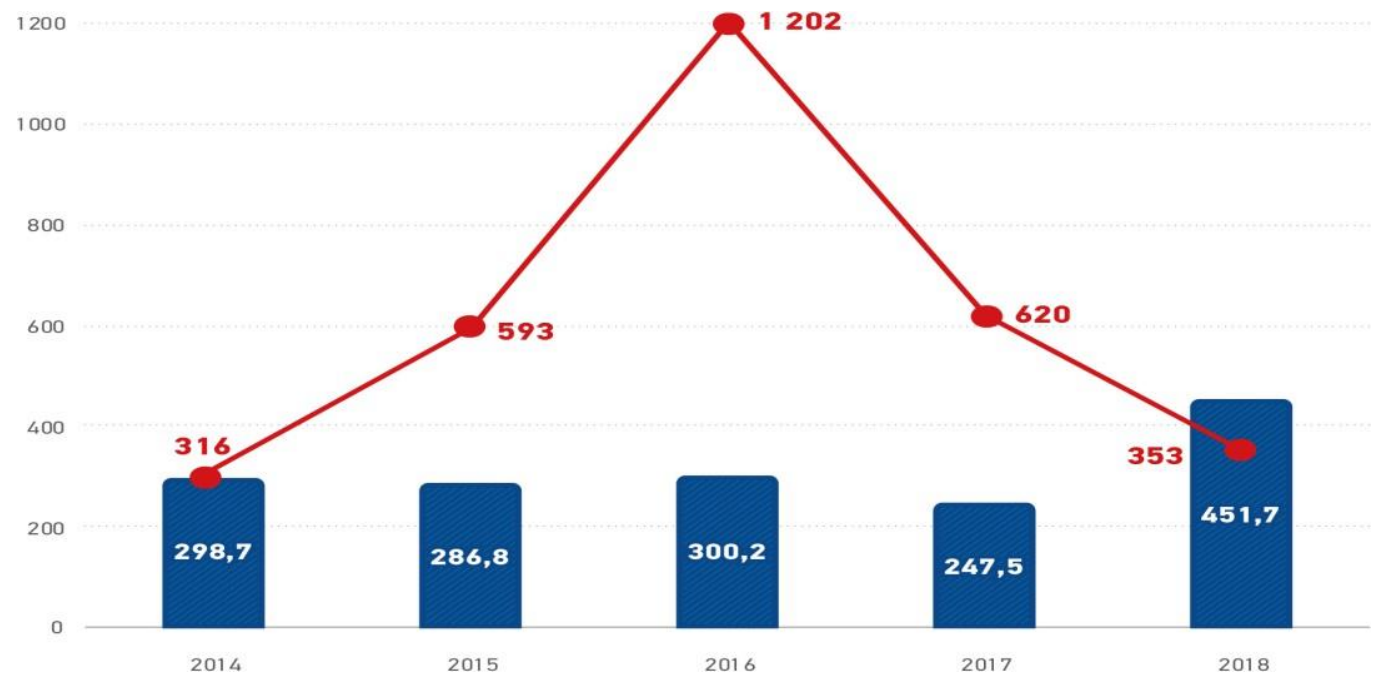

02

The volume of private investment, billion rubles

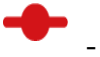

- Number of PPP projects that have passed the commercial closure phase

Figure 4 Dynamics of PPP projects that have passed the stage of commercial closure and the volume of private investment attracted for their implementation by year

Source: data from the National center for public-private partnership

As of 2019, the TOP 5 regions that are leaders in terms of PPP development are: Moscow, Saint Petersburg, Moscow region, Republic of Bashkortostan, and Samara region.

Most public-private partnership projects are implemented in the sphere of transport, housing and utilities, and energy [18-20]. Transport accounts for $59 \%$ of the total investment volume, or 1.3 trillion rubles. While the number of projects implemented in this sector accounts for only $4 \%$. The reverse situation is observed in the housing and utilities and energy sector. $80 \%$ or 2731 projects are in this sector, although in monetary terms this is only a quarter of the total.

Thus, the development of a mechanism for constructive partnership between the state and business will increase the volume of attracted private investment to solve national problems and develop socially important industries. This will make it possible to modernize the industrial and social infrastructure, implement high-risk and costly scientific and technical research. All this will have a positive impact on the life of a particular person and business entity by expanding the number of services provided and increasing their quality, reducing production costs, as well as creating additional jobs, increasing income and improving the quality of life.

\section{THE PERSPECTIVES OF THE RESEARCH}

The existing restrictions in the field of PPP development in Russia are mainly related to the imperfection of the legal framework, especially at the municipal level. Namely, for municipalities, which bear the main burden of maintaining social facilities in proper condition, the PPP mechanism can become a kind of panacea that will improve the living conditions of citizens and stimulate business development without additional budget costs. Therefore, it is necessary to continue research in the field of improving the legal framework and harmonizing tax, budget and land legislation governing the implementation of PPP projects. Further transformation of the legal framework will help to correct the current situation and give additional impetus to the development of the PPP institution in Russia.

\section{REFERENCES}

[1] The World Bank, Available at: https://www.worldbank.org/en/topic/publicprivatepartn erships. 
[2] UNECE, Guiding Principles on People-first Public-Private Partnerships in support of the United Nations Sustainable Development Goals, 21 January 2019, ECE/CECI/2019/5, Available at: https://www.unece.org/fileadmin/DAM/ceci/document s/2019/CICPPP/Official_documents/ECE_CECI_2019 -05-en.pdf.

[3] UNECE, Introduction to People-first PublicPrivate Partnerships in support of the United Nations Sustainable Development Goals, 21 January 2019, ECE/CECI/2019/6, Available at: https://www.unece.org/fileadmin/DAM/ceci/ppp/Stand ards/ECE_CECI_2019_06-en.pdf.

[4] OECD Infrastructure Financing Instruments and Incentives, OECD Publishing, 2015, Available at: http://www.oecd.org/finance/privatepensions/Infrastructure-Financing-Instruments-andIncentives.pdf.

[5] R. Osei-Kyei, A.P.C. Chan, Review of Studies on the Critical Success Factors for Public-Private Partnership (PPP) Projects, International Journal of Project Management 33(6) (2015)1335-1346.

[6] E.A. Alsafran, F.T. Edum-Fotwe, W.E. Lord, Modelling the states of public client participation in public private partnership arrangements, International Journal of Social, Behavioral, Educational, Economic, Business and Industrial Engineering 10(4) (2016) 1077-1084.

[7] A. Sanghi, A. Sundakov, D. Hankinson, Designing and using public-private partnership units in infrastructure: lessons from case studies around the world, World Bank Other Operational Studies 10644, The World Bank, 2017, Available at: https://ideas.repec.org/p/wbk/wboper/10644.html.

[8] A. Marx, The Public-Private Distinction in Global Governance: How Relevant is it in the Case of Voluntary Sustainability Standards?, The Chinese Journal of Global Governance 3 (2017) 1-26.

[9] A. Marx, Public-Private Partnerships for Sustainable Development: Exploring Their Design and Its Impact on Effectiveness, Sustainability 11 (2019) 1087.

[10] I. De Los Ríos-Carmenado, M. Ortuño, M. Rivera, Private-Public Partnership as a Tool to Promote Entrepreneurship for Sustainable Development: WWP
Torrearte Experience, Sustainability 8 (2016) 199. DOI:10.3390/su8030199

[11] O.-K. Robert, A.P.C. Chan, Implementation constraints in public-private partnership: Empirical comparison between developing and developed countries/economies, Journal of Facilities Management 15 (2017) 90-106. DOI: 10.1108/JFM-07-2016-0032

[12] F. Zen, Public-Private Partnership Development in Southeast Asia, 2018, Available at: https://www.adb.org/sites/default/files/publication/444 631/ewp-553-ppp-development-southeast-asia.pdf.

[13] F. Zen, Realizing the Potential of Public-Private Partnerships to Advance Asia's Infrastructure Development, 2019, Available at: https://www.adb.org/sites/default/files/publication/479 396/potential-ppp-asia-infrastructure.pdf.

[14] Market Update. Review of the European PPP Market in 2018. European PPP Expertise Centre and European Investment Bank, PPP Expertise Centre, 2018, Available at:

https://www.eib.org/attachments/epec/epec_ market_update_2018_en.pdf.

[15] European Parliament Resolution on the Green Paper on Services of General Interest, Available at: https://www.europarl.europa.eu/sides/getDoc.do?pubR ef $=-/ /$ EP//TEXT+REPORT + A5-2003$0484+0+\mathrm{DOC}+\mathrm{XML}+\mathrm{V} 0 / / \mathrm{EN} \&$ language $=\mathrm{EN}$.

[16] V.I Tinyakova., N.I. Morozova, M.A. Ziroyan, E.B. Falkovich, Monitoring of human resources and a new educational structure for training specialists as key factors to reactivate the system of consumer cooperation in Russia, Amazonia Investiga 7(17) (2018) 353-359.

[17] N.I. Morozova, Quality of life of the population: economic nature, determinants and directions of assessment, Modern Economy: Problems and Solutions 6(78) (2016) 128-134.

[18] S.A. Belov, Public-private partnership in Russia and foreign countries: legal aspects, Infotropic Media, 2015.

[19] V.A. Tsvetkov, K.K. Zoidov, A.A. Medkov, Public-private partnership - the main form of realization of the transport and transit potential of Russia, Regional Economy 13.1 (2017) 1-12. DOI: 10.17059/2017-1-1 
[20] S.G. Medyantseva, N.V. Kavkaeva, O.N.

Kavkaeva, Public-private partnership projects in the social sphere of the Russian Federation, Journal of Economic Regulation 9(4) (2018) 82-95. DOI:

10.17835/2078- 5429.2018.9.4.082-095 